\title{
COPING AND EMOTIONAL COMFORT OF CAREGIVERS
}

\section{Mária Novysedláková ${ }^{1}$, Katarína Zrubáková $^{2}$, Mariana Magerčiaková ${ }^{3}$,} Eva Morauč́ková ${ }^{4}$

\begin{abstract}
:
Introduction: The aim of this research is to find coping strategies for dealing with stress among caregivers who look after a chronically ill family member and to assess which of the most common emotions they are experiencing.

Methods: We used a standard 28-item questionnaire Brief COPE (Carver, 1997) with Likert scale with values of 6-1 and standardized Variety habitual emotional, subjective well-being in this study (Džuka, Dalbert, 2002). The questionnaire was distributed by nurses who care for ill relatives in the Home Care Agency. We used descriptive statistical methods.

Results: Exploratory data includes answers from 30 respondents, who were caregivers of a patient with chronic illness at home. The average age of respondents was 66.3 years +4.5 , ranged between 56 and 71 years old. Concerning the custodies, these were the most often the life partners - husband / wife (63\%). The average length of treatment was half a year - year $(27 \%)$. Top active strategies for coping with stress were: planning, instrumental social support, acceptance, religiosity, emotional support, with the average from 4.65 to 4.27. The least used coping strategies were humor and drug use. Respondents experienced more frequent negative than positive emotions - pain with average 4.30, sadness 4.24, fear 4.23,

Conclusion: The study shows that the caregivers can select an active strategy to help them overcome difficulties while taking care of the sick. When assessing emotional survival, we found out that respondents had negative emotions.
\end{abstract}

UDC Classification: 615.8; 613.8; DOI: http://dx.doi.org/10.12955/cbup.v6.1276

Keywords: Family caregiver. Brief COPE. Coping strategies. The scale of the subjective emotional well-being.

\section{Introduction}

The caregiver who provides care for a member of the family at home has an important place in the chain of social and health care. According to the European Charter of Family Carers (2007), family caregiver is not a professional person who provides a total or partial basic assistance with daily living activities to a person reliant on the help of others (the dependent person) and its immediate circle. Regular assistance may be provided on a continuous basis and may include various forms of assistance, in particular: treatment, care, help with education and social life, administrative formalities, coordinate, permanent supervision, psychological support, communication, household chores, etc. The term carer refers to the family members, neighbours or friends who provide long-term or substantial and regular care for someone who needs help with daily living activities.

Caregiving, according to Plank et al. (2012, p. 208) "can be a demanding and even all-consuming task that takes a lot of time, psychological energy and physical stamina; therefore, it cannot be assumed that families can cope with the demands care-giving brings." Caregiving challenges have many overwhelming results for families, which in addition can add extra pressure to the normal functioning of a family unit.

The objective of this contribution was to identify the coping strategies of caregivers in caring for chronically ill relatives in a home environment and to assess what emotions caregivers experience most frequently.

\section{Literature review}

A chronic disease (e.g., diabetes, cardiovascular disease, stroke, hypertension,dementia, some cancers, rheumatological diseases, human immunodeficiency virus) can occur and cycle in flare-ups throughout the lifetime. Chronic illnesses, with their effect on the patient's symptoms, mood, and need for emotional and physical support, exert a burden on family members. Additionally, families influence a patient's psychological adjustment and management of the illness, adoption of behaviors that influence recovery, functioning and adherence to treatments (Martire, Lustig et al.,2004).

According to surveys, the disabled population has continued to grow. A person with a disability often has no choice but to rely on his/her family. Supporting a family member with a disability is one of the most challenging experiences. Many preceding studies have reported that family caregivers of a

\footnotetext{
${ }^{1}$ Catholic University in Ruzomberok, Faculty of Health Care, Slovak Republic, maria.novysedlakova @ ku.sk

${ }^{2}$ Catholic University in Ruzomberok, Faculty of Health Care, Slovak Republic, katarina.zrubakova@ku.sk

${ }^{3}$ Catholic University in Ruzomberok, Faculty of Health Care, Slovak Republic, mariana.magerciakova@ku.sk

${ }^{4}$ Catholic University in Ruzomberok, Faculty of Health Care, Slovak Republic, eva.moraucikova,@ku.sk
} 
person with a disability experience deterioration in mental and physical health due to stress (Pearlin, Mullan, Semple, Skart, 1990).

Caregiving has been identified as a chronic stressor that places caregivers at risk for the physical and emotional problem.Caregiving stress is expressed in the form of familial tensions and pressure, which is inevitably experienced owing to the imbalances between the caregiving responsibility and actual capability. Families are put in a situation that is overwhelming, and they experience mental and psychological confusion, which acts as a threat to their physical and mental health. Therefore, it is critical that the family members measure their level of stress and maintain their health. The stress is characterized as a set of requirements of a quantitative or qualitative nature to which a person is unable to respond positively or to deal with. In relation to stress, the stress situation is characterized as a state where the intensity of the stress situation is higher than the chance, respectively the ability of a man to cope with the situation (Skinner, Edge, Altman, Sherwood, 2003). Overloading the caregiver is a situation in which an individual providing the care in domestic environment experiences a physical, mental, social and / or financial burden caused by such care.

Coping is defined as the process of executing a response to a stressor, where stress is viewed as the experience of encountering relevant difficulties in one's goal-related efforts (Lazarus, Folkamn, 1984). Within the framework of self-regulation theory (Greenglass, Fiksenbaum, 2009), explicitly highlighted the relationships among stress, coping, and goals. These authors (Li \& Lambert, 2008; Bally \& Šiňanská, 2014; Pearlin, Mullan, Semple, Skaff,1990) affirmed that stress is closely linked to the pursuit of goals or to the avoidance of threats. Stress exists when an individual perceives the achievement of the desired goal as impossible or detects possible future punishments. People's coping responses to threats and stressors are key determinants of their psychological adjustment and wellbeing. Coping with the stress of life can influence mental health and well being. Psychological wellbeing focuses on the positive and negative emotions and increase pleasure and decreases negative moods (Ryff,1989). How individuals cope with stressful situation determines health and well being of people in situation. Efficient coping leads to good results such as happiness, personal development, life satisfaction (Endler, Parker,1994). In a longitudinal study of caregivers, it was confirmed that caregivers with the highest burden had a higher level of anxiety, anger and physical health problems (Bally, Šiňanská, 2014).Thus, it is important to reliably and validly assess individual coping thoughts or actions.

Coping is a very broad concept, and several distinctions have been made within this broad domain. One important distinction in the study of coping is the difference between situational coping responses and dispositional coping styles. The former correspond to the ways people react and cope with specific difficulties and stressful circumstances, whereas the latter are defined as tendencies to use specific coping reactions to a greater or lesser degree under stress. Empirical evidence suggests that the adoption of situational coping responses is influenced by several different aspects, such as socioeconomic status, the dispositional coping style (Carver \& Scheier, 1994), dispositional optimism causal attributions and the controllability of stressors (Coyle \& Vera, 2013). Previous research by Zou et al. (2013) led to the present study, which aspires to understand how carers develop positive and negative coping strategies to deal with their responsibilities, accept their actual life, accomplish personal well-being, and achieve their ideal life amidst their obligations as caregivers. Greenglass and Fiksenbaum (2009) report that coping is a reaction to stressful experiences, and a strategy is used once stress had been experienced. Coping is how people deal with daily problems. Shiota (2006) suggests the correct coping strategies increase wellbeing and reduce stress.

Fears and concerns about how to cope with the illness or disability of the recipient, and about how to organise the various aspects of caring, are particularly frequent (Plank et al., 2012).

Coping with response depends not only on the assessment of the situation but also on other environmental factors and limitations as well as their own abilities, attitudes, and knowledge. These personal determinants can be, for example, self-assessment, self-perception, self-efficacy, self-esteem (Baumgartner,2010).

As a basic prerequisite for capturing carers who are prone to have health risks associated with performing their roles, it is best to monitor the degree of the burden and evaluate it. There is a set of questionnaires for monitoring and evaluating the intensity of it. 
The Brief COPE (Carver, 1997) is one of the most frequently used self-report measures of coping responses. However, there is a lack of empirical evidence regarding its psychometric properties. The main aim of this study was to examine the dimensionality of the Brief COPE by comparing five different factor models highlighted by previous studies. Moreover, given the theoretical link between coping and goals, the second aim was to evaluate the associations between coping responses and goalrelated variables of commitment and progress.

To overcome this potential shortcoming, Carver (1997) developed the Brief COPE, an abridged version of the COPE. The Brief COPE measures 14 theoretically identified coping responses: Selfdistraction, Active coping, Denial, Substance use, Use of emotional support, Use of instrumental support, Behavioral disengagement, Venting, Positive reframing, Planning, Humor, Acceptance, Religion, and Self-blame. It represents a way to rapidly measure coping responses because it is a short 28 -item self-report questionnaire with two items for each of the measured coping strategies. The list below reports items of the Brief COPE.

Several self-report measures of coping responses have been developed and are currently available, including the Ways of Coping Questionnaire (WCQ; Folkman \& Lazarus, 1988), the Coping Orientation to Problems Experienced (COPE; Carver, Scheier, \& Weintraub, 1989), the Multidimensional Coping Inventory (MCI, Endler \& Parker, 1990), the Coping Inventory for Stressful Situations (CISS; Endler \& Parker, 1994), and the Coping Responses Inventory-Youth (CRIYouth; Moos, 1993). All of these measures validly and reliably assess both approach and avoidance coping responses and both problem- and emotion-focused strategies. However, one possible drawback of these scales is their relatively extended length, ranging from 48 to 66 items, which may limit their usefulness in long research protocols and in clinical settings.

The Brief COPE has recently been used in empirical research evaluating the role of coping in facing different types of stressors, such as heart failure (Bean, Gibson, Flattery, Duncan, \& Hess, 2009; Carels et al., 2004; Klein, Turvey, \& Pies, 2007;), HIV disease (Sanjuán, Molero, Fuster, \& Nouvilas, 2013), caregiving for a family member with mental illness (Wrosch, Amir, \& Miller, 2011). However, the Brief COPE's theoretically based 14-factor structure has received little empirical support.

\section{Data and Methodology}

The COPE Inventory was developed to assess a broad range of coping responses. We used the Brief COPE survey (Carver, 1997, p. 92-100). The Brief COPE is a self-report questionnaire used to assess a number of different coping behaviors and thoughts a person may have in response to a specific situation. It is made up of 14 subscales: self-distraction items 1 and 19, active coping items 2 and 7, denial items 3 and 8 , substance use items 4 and 11, use of emotional support items 5 and 15, use of instrumental support items 10 and 23, behavioral disengagement items 6 and 16, venting items 9 and 21, positive reframing items 12 and 17, planning items 14 and 25, humor items 18 and 28, acceptance 20 and 24, religion items 22 and 27, and self-blame items 13 and 26. 28 coping behaviors and thoughts ( 2 items for each subscale) are rated on the frequency of use by the participant with a

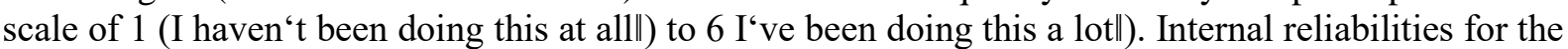
14 subscales range from $\alpha=0.57-0.90$ (Carver, 1997). The second part of the questionnaire consisted of a set of questions that were focused on the survey of sociodemographic and personality characteristics of the respondents. The questionnaire was validated in the English language. For the purpose of our work the original version translated into English was used. The translation was made by a bilingual translator.

Another tool used was the Standardized Scale of the Emotional Subjective Well-Being (Dukka, Dalbert, 2002, pp.234-250). Cronbach's $\alpha$ coefficient $=0.77$. The scale contains 4 positive states and six negative states. Respondents answered to the Likert scale with values 1-6. (Džuka, Dalbert, 2002, p. 234-250). The data obtained were processed using the SPSS 16.0 for Windows. First, we use statistical tests to calculate the frequencies and the formation of the averages, which allowed us to find out what coping strategies are used by caregivers most often. The research was carried out in the year 2017. We conducted the questionnaire administration by a nurse in a Home Nursing Care Agency, that selected appropriate respondents. 


\section{Results}

The survey sample consisted of the caregiver who provides care for a member of the family at home. There were 30 respondents, 21 female and 9 male. The average age of respondents was 66.3 years \pm 4.5. The range of the participant's age was between 41 and 72 years old. In research, we have grouped this respondent who fulfilled the following criteria: carer, for as long as possible providing care for a sick family member; willingness to cooperate. Respondents in relation to the patient were as a life partner - wife/husband (63\%), daughter/son of $27 \%$, daughter-in-law 3\%, aunt/uncle 7\%. In terms of family competence needed to provide care were 19 life partners, 8 children, and 3 relatives. Respondents in marital status were married (87\%).

The length of the care provided is in the sample ranged from 1 year to 7 years. The average length of caring was 2 years \pm 0.55 (Table 1 ).

\begin{tabular}{|c|c|c|}
\hline \multicolumn{3}{|l|}{ Table 1: Length of care } \\
\hline Total & 30 & $100 \%$ \\
\hline Length of the care & Absolute Frequency (N) & Relative Frequency (\%) \\
\hline$\leq 1 / 2$ year & 8 & 27 \\
\hline$\geq 1 / 2 \leq 1$ year & 7 & 23 \\
\hline$>1 \leq 3$ years & 6 & 20 \\
\hline$>3 \leq 5$ years & 5 & 17 \\
\hline$>5$ years & 4 & 13 \\
\hline Total & 30 & 100 \\
\hline $\begin{array}{l}\text { Time spent on } \\
\text { caregiving (per days) }\end{array}$ & Absolute Frequency (N) & Relative Frequency ( $\%$ ) \\
\hline$<5 \mathrm{hrs}$ & 3 & 10 \\
\hline 5 to $10 \mathrm{hrs}$ & 4 & 13 \\
\hline$\geq 10 \mathrm{hrs}$ & 23 & 77 \\
\hline Total & 30 & 100 \\
\hline
\end{tabular}

Caregivers cared for relatives with the diseases like stroke (30\%), oncological disease (23\%), in a condition after amputations (17\%), with immobility (17\%) (Table 2).

Table 2: Type of disability

\begin{tabular}{|l|c|c|}
\hline Type of disability & Absolute Frequency (N) & Relative Frequency (\%) \\
\hline Post - stroke & 9 & 30 \\
\hline Oncological disease & 7 & 23 \\
\hline Amputation of leg & 5 & 17 \\
\hline immobility & 5 & 17 \\
\hline ulcus cruris & 3 & 10 \\
\hline Diabetes mellitus & 3 & 10 \\
\hline Fractures & 2 & 7 \\
\hline Injuries & 3 & 10 \\
\hline Sclerosis multiplex & 2 & 7 \\
\hline Alzheimer's disease & 1 & 3 \\
\hline Total & 30 & 100 \\
\hline
\end{tabular}

Source: Authors

Subjectively, the caregivers assess their physical and mental state as mildly worse (30\%), bad (30\%), or normal (30\%) (Table 3). Caregivers subjectively evaluated their physical and mental status as a bad state $(30 \%)$, mildly worse state $(37 \%)$, normal state $(30 \%)$ (Table 3$)$. 


Table 3: Current mental and physical state
\begin{tabular}{|l|c|c|}
\hline Current mental and physical state & Absolute Frequency (N) & Relative Frequency (\%) \\
\hline 1 - very bad state & 1 & 3 \\
\hline 2 - bad state & 9 & 30 \\
\hline 3 - mildly worse state & 11 & 37 \\
\hline 4 - normal state & 9 & 30 \\
\hline 5 - very good state & 30 & 100 \\
\hline Total & & \\
\hline
\end{tabular}
Source: Authors

We present answers of respondents on to individual items sorted into 14 subcategories. The results of the research of coping strategies employed by the caregivers showed the usage of effective strategies: planning - average 4.30, SD $\pm 0,96$; instrumental social support - average 4.63, SD \pm 0.97 ; acceptance - average $4.50, \mathrm{SD} \pm 1,20$; religion - average $\pm 4.30, \mathrm{SD} 1.44$; emotional support average $4.27, \mathrm{SD} \pm 0.99$. In the category of ineffective coping strategies were self-distraction average $3.63, \mathrm{SD} \pm 1.53$; denial - average $2.80 ; \mathrm{SD} \pm 1.52$; self-blame - average $2.48 \mathrm{SD} \pm 1.29$ (Table 4).

Table 4: Coping strategies
\begin{tabular}{|l|l|l|l|}
\hline \multicolumn{1}{|c|}{ Coping strategies } & Arithmetic mean & Standard deviation \\
\hline$(+)$ & planning & 4.65 & 0.96 \\
\hline$(+)$ & instrumental social support & 4.63 & 0.97 \\
\hline$(+)$ & acceptance & 4.50 & 1.20 \\
\hline$(+)$ & religion & 4.30 & 1.44 \\
\hline$(+)$ & emotional support & 4.27 & 0.99 \\
\hline$(+)$ & self-distraction & 3.63 & 1.53 \\
\hline$(+)$ & active coping & 3.52 & 1.03 \\
\hline$(+)$ & venting & 3.22 & 1.01 \\
\hline$(+)$ & positive reframing & 3.08 & 1.16 \\
\hline$(-)$ & denial & 2.80 & 1.52 \\
\hline$(-)$ & self-blame & 2.48 & 1.29 \\
\hline$(+)$ & disengaged behavior & 2.43 & 1.11 \\
\hline$(+)$ & humor & 1.53 & 0.78 \\
\hline$(-)$ & drug usage & 1.35 & 0.72 \\
\hline
\end{tabular}
$\mathrm{p}<0.05$

\section{Source: Authors}

Respondents felt negative emotions more often than positive ones. The highest average of the negative emotions was reached pain $(4,30), \mathrm{SD} \pm 1,32$; sadness with an average of 4,24, $\mathrm{SD} \pm 1,24$; and regarding the positive emotions, joy achieved an average of $3,10, \mathrm{SD} \pm 0,98$. (Table 5).

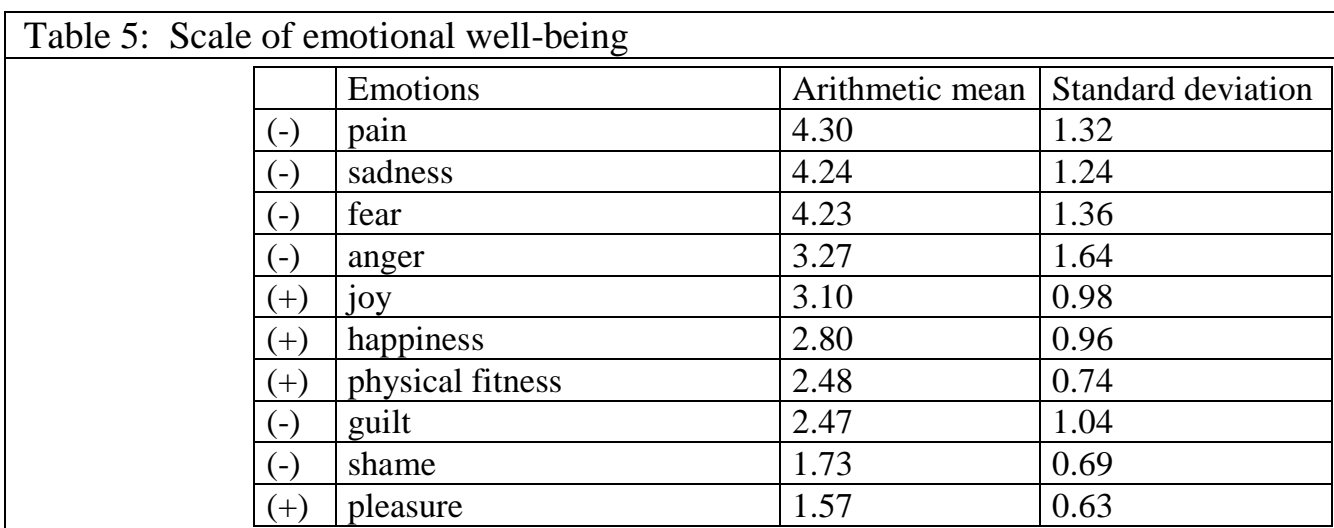

$\mathrm{p}<0.05$

Source: Authors 


\section{Discussion}

To meet our objective, we used the questionnaire, Brief COPE, which offered respondents the opportunity to choose from several coping strategies.

The dimensionality of the situational Brief COPE has been analyzed in three further studies. However, none of these studies performed a confirmatory factor analysis (CFA) to assess the 14-factor structure proposed by Carver (1997). Specifically, two (i.e., Carver, 1997; Miyazaki, Bodenhorn, Zalaquett, \& $\mathrm{Ng}, 2008$ ) of the three studies performed an exploratory factor analysis (EFA), whereas the fourth study (Knoll, Rieckmann, \& Schwarzer, 2005) performed a second-order CFA to further summarize the 14 dimensions into four higher-order factors. Carver (1997) was the first to propose a factor structure different from the 14-factor model. He identified, through an EFA, only nine factors with eigenvalues greater than one. Five a priori scales formed distinct factors: Substance use, Religion, Humor, Behavioral disengagement, and Acceptance. Another factor was formed by Active coping, Planning, and Positive reframing items. Similarly, three other factors were formed by items from two distinct a priori scales. The Use of emotional support and Use of instrumental support items loaded together on a single factor. Another factor was formed by the Venting and Self-distraction items, and items from the Denial and Self-blame dimensions loaded together on another factor.

A person applying strategy, planning, active coping, acceptance, realizes the presence of a problem, faces it actively and plans their next steps. Such a person is able to explain this situation to themselves and, therefore, make it better manageable and tolerable. It is typical for this person not to give in the particular situation or to give up, but actually to solve it actively (Šolcová, Lukavský, 2006).

The results of the research on coping strategies used by caregivers showed strategies focused on planning, instrumental social support, acceptance, religion, emotional support. Between those strategies, there were minimal differences.

Planning strategies preferred the most by the respondents in our file were those that we consider very positive. Planning as a coping strategy represents the thinking carers, what steps can be taken to cope with stress effectively. Li, Lambert (2008) report that the nurses, who belong to the caregiver professions mostly use just coping strategy planning.

The person who uses the strategy of social support seeking instrumental social support has probably a strong social background, is aware of their relationships with people and in dealing with stressful situations is not afraid to ask others for help.

This help can acquire psychological support, but can also act on the support of financial or material. At the same time, we see that this person in my emotions does not suppress, but vents are probably among your loved ones. Again this is a functional coping.

We for this coping strategy used the term social support in the literature or the search for emotional support in the nearest surroundings (Carver, Scheier, Weintraub, 1989)

There were also minimal differences between the coping strategies of religion and emotional support. Religion and spirituality are a factor implicated in coping strategies. Researchers have conferred over the positive and negative aspects of religion and spirituality and the type of relationship the individual has with God. Deferring the problem to God to solve has a negative effect, for example, anxiety. A positive effect is when an individual sees God as a partner in problem-solving, which results in a positive outcome, such as greater empowerment. Caregivers who made more use of positive religious or spiritual coping methods showed reduced levels of negative outcomes and higher levels of positive outcomes Ruiselová et al. (2006). Coping focused on the problem concentrates on changing or managing a load situation, and its main aim is to eliminate unpleasant results of the load situation or differentiating between sources for overcoming it (Bally, Šiňanská, 2014, p.154-159).

Coping oriented to emotional experience is characterized by the effort of the individual to control the city coming under the influence of stress and regulating the emotional response to the force of the load (Gajdošová, 2009). The first task of the effective coping should be to reduce the intensity of negative emotions, which could prevent the use of active strategies for coping with the load (Baumgartner et al., 2010). Individuals who have an optimistic approach more effectively handle the stress of the situation and the solution of problems. 
The strategy of positive reframing leads to acceptance of the problem, is able to get him to realize even in other contexts, look at it from the other site and see the positive. A great role also plays humor, this man, his situation does not take deadly seriously and is able to lighten up.

Ineffective strategies - self-blame, denial and/or suppression were used to a lesser extent. The lowest frequency of occurrence was identified in the use of the supporting, soothing substances (such as alcohol and drugs), what can be assessed positively. It is a strategy which is clearly broken and passive.

A person in a stress situation using this strategy gives up the possibility to cope with stress, forfeits despair, remorse and turns to also alcohol or other addictive substances. This strategy can be found in the literature as a dysfunctional coping strategy, as defined by Carver, Scheier, and Weintraub (1989).

Literary reports show that there is a growing number of researches focusing on the exploration of the lives and needs of the family carers of relatives with different needs, as a result of the occurrence of Alzheimer's disease, cancer or other diseases which occur more frequently among the population. (Cisek, Wilczek-Ružyczka, Gniadek, Zdanowska, 2005; Haley, 2003).

We analyzed the frequency of positive and negative emotions on the Scale of emotional, habitual subjective well-being (Džuka, Dalbert, 2002, p.234-250). The authors of the scale based it on the assumption that habituality can be understood as the frequency of a feeling or a state. Respondents felt more negative than positive emotions. The most frequent negative emotions were pain, sadness, and fear. The least frequent positive emotions were joy and happiness. According to Džuka, Dalbert, (2002, p.234-250), negative emotions are conditioned mainly genetically (temperamentally), while positive emotions are primarily affected by the environment.

If a situation is assessed as damaging, it is accompanied by negative emotions, such as sadness or anger. Positive emotions, such as happiness, relief, and pride occur when a situation is solved pleasantly. Feeling positive emotions shows that people are able to recharge their resources of physical and mental energy in difficult life situations (Folkman, 2006, p. 3-14).

\section{Conclusion}

The aim of this research was to assess and review the strategies of caregivers during taking care of a sick relative. Our aims were also identifying the emotions felt by caregivers, specific coping styles, to what extent they were used, and identifying potentially damaging coping strategies. Coping strategies and the use of them is the aim of studying psychology, but also in terms of the importance of nursing knowledge and identifying ways of coping. A complex assessment of the care recipient and the caregiver, using available assessment tools, can help to effectively address the issue of caregiver's burden when caring for a chronically ill in practice. The aim of the comprehensive approach is to improve the quality of life of not only the chronically ill person but also the family providing the home care.

\section{References}

Bally, D. \& Šiňanská, K. (2014). Stres ako súčast' profesie sociálnych pracovníkov. [Stress as part of the profession of social workers]. Rizikové správanie v teórii a praxi sociálnej práce. Košice: UPJŠ FF, 154-159.

Baumargartner, F., Molčanová, Z. \& Chylová, M. (2010). Emočná inteligencia vo vzt'ahu ku copingu. [Emotional intelligence in relation to coping].In Ruisel, I., Prokopč́ková, A. (eds.). Kognitívny portrét človeka. [A cognitive portrait of a man]. Bratislava: Ústav experimentálnej medicíny SAV,186-204.

Bean, M. K., Gibson, D., Flattery, M., Duncan, A., \& Hess, M. (2009). Psychosocial factors, quality of life, and psychological distress: Ethnic differences in patients with heart failure. Progress in Cardiovascular Nursing, 24(4), 4131-140. Bosson, J. K., Johnson, A. B\& Niederhoffer, K. (2006). Interpersonal chemistry through negativity: Bonding by sharing negative attitudes about others. Personal Relationship, 13 (2),135-150.

Carels, R. A., Musher-Eizenman, D., Cacciapaglia, H., Pérez-Benítez, C. I., Christie, S., \& O'Brien, W. (2004). Psychosocial functioning and physical symptoms in heart failure patients: A within-individual approach. Journal of Psychosomatic Research, 56(1), 195-101.

Carver, C. S. (1997). You want to measure coping but your protocol's too long: Consider the Brief COPE. International Journal of Behavioral Medicine, 4, 92-100.

Carver, C. S., Scheier, M. F., \& Weintraub, K. J. (1989). Assessing coping strategies: A theoretically based approach. Journal of Personality and Social Psychology, 56(2), 2267-283.

Cisek M, Wilczek-Ružyczka E, Gniadek A, \& Zdanowska A. (2005) Preparation the family to care of the patient with Alzhaimer's disease: Roczniki Akademii Medycznej w Białymstoku 50(1):116-118. 
Coyle, L. D., \& Vera, E. M. (2013). Uncontrollable stress, coping, and subjective well-being in urban adolescents. Journal of Youth Studies, 16(3), 3391-403.

Džuka, J. \&Dalbert, C. (2002). Vývoj a overenie validity Škál emocionálnej habituálnej subjektívnej pohody (SEHP). [Development and Validation Validity Scale of emotional habitual subjective well-being] Československá psychologie, 46 (3), $234-250$.

Endler, N. S., \& Parker, J. D. A. (1990). Multidimensional assessment of coping: A critical evaluation. Journal of Personality and Social Psychology, 58(5), 5844-854.

Endler, N. S., \& Parker, J. D. A. (1994). Assessment of multidimensional coping: Task, emotion, and avoidance strategies. Psychological Assessment, 6(1), 150-60.

Európska charta pre rodinných opatrovatel’ov. (2007). [European Charter of Family Carers] [online]. (2007). [cit. 2018.0510]. Dostupné na: www.employment.gov.sk/index.php?id=11228

Falb, M. D., \& Pargament, K. I. (2013). Buddhist coping predicts psychological outcomes among end-of-life caregivers.Psychology of Religion and Spirituality, 5(4), 252-262.

Folkman, S. (2006). The case for positive emotions in the stress process. Anxiety, stress \&coping, 21(1), 3-14.

Folkman, S., \& Lazarus, R. S. (1988). Manual for the Ways of Coping Questionnaire. Palo Alto, CA: Consulting Psychologists Press.

Gajdošová, E. (2009). Výber psychologických disciplín. [Selection of psychological disciplines]. Bratislava: Príroda, Greenglass, E. R., \& Fiksenbaum, L. (2009). Proactive coping, positive affect, and well-being: Testing for mediation using path analysis. European Psychologist, 14(1), 29-39. doi:10.1027/1016-9040.14.1.29

Halama, P. \& Bakošová, K. (2009). Meaning in life as a moderator of the relationship between perceived stress and coping. Studia psychologica. 51, (2-3): 143-148.

Haley, W. E. (2003). Family caregivers of elderly patients with cancer: Understanding and minimizing the burden of care. 1( 2). November/december 2003. www.SupportiveOncology.net

Hepburn, K. W. et al. (2001). Dementia family caregiver training: Aff ecting beliefs about caregiving and caregiver outcomes. Journal of the American Geriatrics Society, 43, (4), 450-457.

Klein, D. M., Turvey, C. L., \& Pies, C. J. (2007). Relationship of coping styles with quality of life and depressive symptoms in older heart failure patients. Journal of Aging and Health, 19(1), 122-38.

Kliment, Pavel. (2014). Zvládací (copingové) odpovědi v pomáhajících profesích. [Managing (coping) responses in helping professions].1.Olomouc: Univerzita Palackého v Olomouci.

Knoll, N., Rieckmann, N., \& Schwarzer, R. (2005). Coping as a mediator between personality and stress outcomes: A longitudinal study with cataract surgery patients. European Journal of Personality, 19(3), 3229-247.

Lazarus, R.S. \& Folkman, S. (1984). Stress, Appraisal and Coping. New York : Springer Publishing Company,1984. s. 445. Li, J.; \& Lambert, V.A. (2008). Workplace stressors, coping, demographics and job satisfactionin Chinese intensive care nurses. Nursing in critical care. 13(1), 12-24.

Miyazaki, Y., Bodenhorn, N., Zalaquett, C., \& Ng, K. (2008). Factorial structure of Brief COPE for international students attending U.S. colleges. College Student Journal, 42(3), 3795-806.

Martire LY, Lustig AP, et al. (2004). Is it beneficial to involve a family member. Health Psychol 2004;23:599-611.

Moos, R. H. (1993). CRI-Youth Form Professional Manual. Odessa, FL: Psychological Assessment Resources, Inc.

Pearlin L. I., Mullan J. T., Semple S. J., \& Skaff M. M. (1990). Caregiving and the stress process: an overview of concepts and their measures. The Gerontologist. 30(5), 583-594.

Plank, A., Mazzoni, V., \& Cavada, L. (2012). Becoming a caregiver: New family carers' experience during the transition from hospital to home. Journal of Clinical Nursing, 21(13/14), 2072-2082.

Ryff, C. D. (1989). Happiness is everything, or is it? Explorations on the meaning of psychological well being. Journal of Personality and Social Psychology,57(6):1069-81.

Ruiselová, Z. et al. (2006). Štýly zvládania zát'aže a osobnost'. [Styles of burden management and personality] Bratislava: Slovak Academic Press, 9-20.

Sanjuán, P., Molero, F., Fuster, M. J., \& Nouvilas, E. (2013). Coping with HIV related stigma and well-being. Journal of Happiness Studies, 14(2), 2709-722.

Shiota, M. N. (2006). Silver linings and candles in the dark: Differences among positive coping strategies in predicting subjective well-being. Emotion, 6(2), 335-339. doi:10.1037/1528-3542.6.2.335

Skinne E. A., Edge, K., Altman, J., \& Sherwood, H. (2003). Searching for the structure of coping: A review and critique of category systems for classifying ways of coping. Psychol Bull. 2003;129(2):216-69.

Šolcová, I., \& Lukavský, J. (2006). Dotazník proaktivního zvládání životních nároků. Československá psychologie 50 (2), 148-162.

Tabaková, M. (2009). Doména Rola - vzt’ahy. In E. Gurková, et al., Vybrané ošetrovatel'ské diagnózy v klinickej praxi (pp. 119-125).Martin: Osveta.

Wrosch, C., Amir, E., \& Miller, G. E. (2011). Goal adjustment capacities, coping, and subjective well-being: The sample case of caregiving for a family member with mental illness. Journal of Personality and Social Psychology, 100(5), 5934-946.

Zou, C., Schimmack, U., \& Gere, J. (2013). The validity of well-being measures: A multiple-indicator-multiple-rater model. Psychological Assessment, 25(4), 1247-1254. doi:10.1037/a0033902 